\title{
Keragaman Massa Abnormal Superfisial pada Mencit (Mus musculus) di Malang Raya
}

\author{
(THE VARIATION OF SUPERFICIAL ABNORMAL MASSES \\ OF MICE (MUS MUSCULUS) IN MALANG RAYA)
}

\author{
Andreas Bandang Hardian 1*, Sang Ayu Putri Aristya Dewi², \\ Maulidi Robingi Mardiyani Wukirani², Essly Hervianingsih Adha ${ }^{2}$ \\ ${ }^{1}$ Laboratorium Patologi Anatomi Veteriner \\ 2Mahasiswa Sarjana Kedokteran Hewan \\ Fakultas Kedokteran Hewan, Universitas Brawijaya \\ Jl. Puncak Dieng, Kunci, Kalisongo, Dau, \\ Malang, Jawa Timur, Indonesia 65151 \\ *Email: andreasbandangh@ub.ac.id
}

\begin{abstract}
Mice are known as laboratory animals which are easily bred worldwide for various purposes. Several strains have been introduced and widely used in either experimental or comparative studies, however the genetic control and other breeding aspects may not well managed especially in traditional breeding centres. Maintenance failure in the mice breeding management may lead to some disease incidences causing high economic loss. The presences of abnormal superficial masses are deemed to be visible disease which potentially reduces breeding performance and life expectancy of mice. This study aimed to explore the variation and morphologic characteristic of several abnormal superficial masses in mice bred in Malang Raya, East Java. Atotal of 54 mice with visible abnormal superficial masses were collected from seven traditional breeding centre and consecutively euthanized according to the standard manner. We assessed the gross aspects of the masses as well as any specific histopathologic features following the routine procedure. Cytologic examination was made through fine needle aspiration and Giemsa-based staining. Two morphologic types were recognized: neoplastic and nonneoplastic masses. Grossly, these three types of masses showed no significant difference of characteristic. Cytologically, the neoplastic masses presented more cellular resembling epithelial cells. The cytology of nonneoplastic masses predominantly showed leukocytes and erythrocytes. Histopathologic architecture of 36 neoplastic masses confirmed the presence of mammary adenocarcinoma whereas the nonneoplastic masses varied from subcutaneous abscesses (13), hematoma (1), crusts (2), to nodular granulation (2). The conclusion is that the superficial abnormal mass that appears in mice bred in Malang Raya can be in the form of adenocarcinoma, subcutaneous abscess, and hematoma. The incidence of adenocarcinoma dominated the type of mass found, followed by subcutaneous abscess and hematoma.
\end{abstract}

Keywords: mice; neoplastic; nonneoplastic; masses

\begin{abstract}
ABSTRAK
Mencit dikenal sebagai salah satu jenis hewan coba yang mudah dikembangbiakan. Beberapa galur mencit telah digunakan secara luas untuk tujuan riset eksperimental maupun komparatif. Akan tetapi, kontrol genetik dan beberapa aspek pemeliharaan lainnya seringkali kurang diperhatikan terutama pada peternakan mencit tradisional. Hal ini dapat memicu kemunculan beberapa jenis penyakit yang menyebabkan kerugian ekonomi peternak. Salah satu penyakit akibat rendahnya kualitas manajemen pemeliharaan mencit adalah kemunculan massa abnormal superfisial. Studi ini bertujuan untuk mengeksplorasi variasi dan karakter morfologis dari temuan massa abnormal superfisial dari mencitmencit di Malang Raya. Sebanyak 54 ekor mencit dengan massa abnormal superfisial dikoleksi dari tujuh peternakan mencit dan dieutanasi berdasar aturan berlaku. Pemeriksaan makroskopik dan mikroskopik dilakukan dengan prosedur standar. Pemeriksaan sitologi dilakukan dengan prosedur Fine Needle Aspiration dengan pewarnaan Giemsa. Dua jenis morfologi utama yang dapat dikenali dikategorikan sebagai massa non-neoplastik dan nonneoplastik. Pemeriksaan sitologi pada massa neoplastik
\end{abstract}


menunjukkan selularitas yang tinggi didominasi sel-sel epitelial sedangkan pada massa nonneoplastik didominasi oleh leukosit dan eritrosit. Arsitektur histopatologi dari 36 massa neoplastik menunjukkan karakter adenokarsinoma mammae sedangkan pada massa noneoplastik lebih bervariasi antara lain abses subkutan (13), hematoma (1), krusta (2), dan nodul granulasi (2). Simpulannya adalah massa abnormal superfisial yang muncul pada mencit-mencit yang dibudidayakan di Malang Raya dapat berupa adenokarsinoma, abses subkutan, dan hematoma. Kejadian adenokarsinoma mendominasi jenis massa yang ditemukan disusul oleh abses subkutan dan hematoma.

Kata-kata kunci: mencit; massa; neoplastik; nonneoplastik

\section{PENDAHULUAN}

Mencit dan tikus merupakan salah satu jenis hewan yang dibudidayakan sebagai hewan model baik untuk kepentingan penelitian, pakan ular maupun tujuan lainnya. Berbagai jenis penyakit telah dilaporkan menyerang mencit budidaya. Salah satu jenis penyakit yang sering ditemukan pada mencit dan tikus budidaya adalah penyakit neoplastik (Prejean et al., 1973; Weber, 2017). Secara fisik, penyakit neoplastik pada mencit hanya terlihat jika lesi tumbuh di superfisial sehingga menyebabkan tonjolan massa di bawah permukaan kulit. Hal ini sulit dibedakan dengan beberapa jenis penyakit lain yang memiliki lesi yang sama seperti abses, kista ataupun bekuan darah (hematoma).

Massa abnormal yang tumbuh di bawah permukaan kulit dapat mengganggu performa kesehatan dan reproduksi mencit budidaya. Massa abnormal ini bisa disebabkan oleh berbagai hal antara lain infeksi, tumor, dan hernia. Infeksi merupakan salah satu yang paling umum terjadi pada mencit budidaya (Kengkom dan Ampawong, 2017; Weber, 2017). Berbagai jenis tumor juga sering ditemui pada mencit budidaya, antara lain tumor kelenjar susu (adenoma-adenokarsinoma mammae), tumor adiposa (lipoma-liposarkoma), tumor jaringan ikat (fibroma-fibrosarkoma) (Prejean et al., 1973).

Pemeriksaan histopatologi merupakan metode standar yang dilakukan untuk membantu menegakkan diagnosis berdasar karakter perubahan histologi arsitektur jaringan (lesi) yang terpapar penyakit. Metode ini membutuhkan waktu lebih lama dan tahapan proses yang panjang untuk menentukan jenis massa yang muncul pada tubuh mencit. Untuk itu, diperlukan metode yang lebih sederhana yang mampu mendeteksi lebih cepat jenis massa abnormal yang tumbuh pada mencit. Salah satu metode yang bisa digunakan adalah pemeriksaan sitologi. Kajian ini bertujuan untuk memberikan gambaran keragaman massa abnormal superfisial pada mencit yang dibudidayakan di Malang Raya (Kota Malang, Kabupaten Malang, dan Kota Batu) berdasar gambaran sitologi, makroskopik, dan histopatologi lesi. Pengetahuan tentang jenis-jenis massa abnormal superfisial pada mencit dapat digunakan untuk memprediksi patogenesis kemunculan spontan massa-massa tersebut sehingga penurunan performa mencit akibat penyakit dapat dicegah melalui perbaikan manajemen pemeliharan.

\section{METODE PENELITIAN}

\section{Koleksi Spesimen}

Koleksi sampel dilaksanakan berdasar dokumen laik etik No. 071-KEP-UB-2020. Sebanyak 54 ekor mencit berumur 2-8 bulan yang memiliki bobot badan 10-47,5 g dengan massa abnormal superfisial yang tampak secara makroskopik diambil sebagai spesimen. Spesimen berasal dari tujuh peternakan mencit yang berada di Malang Raya dari bulan Juli hingga Agustus 2020. Euthanasia pada mencit dilakukan berdasar protokol euthanasia dari American Veterinary Medical Association (AVMA) (Underwood dan Anthony, 2020). Proses nekropsi dilakukan setelah memastikan bahwa mencit sudah benar-benar mati. Protokol nekropsi mengikuti prosedur standar nekropsi pada mencit seperti dijelaskan oleh Parkinson et al. (2011)

\section{Pemeriksaan Sitologi}

Pemeriksaan sitologi dilakukan dengan melakukan Fine Needle Aspiration (FNA) pada massa yang terlihat pada permukaan tubuh di tiga titik berbeda. Metode FNA dilakukan sesuai dengan deskripsi dari Ghartimagar et al. (2011) dan Kiehl et al. (2016) dengan jarum $23 \mathrm{G}$ dan syringe $3 \mathrm{~mL}$. Jarum ditusukkan pada massa di tiga titik berbeda. Syringe diisi udara hingga maksimal kemudian dipasangkan dengan jarum. Partikel jaringan yang berada di dalam 
jarum kemudian disemprotkan ke kaca obyek. Fiksasi dilakukan dengan menggunakan methanol lalu diwarnai dengan Giemsa 10\% (Giemsa's azur eosin methylene blue solution ${ }^{\circledR}$, Merck KGaA, Darmstadt, Germany) dengan inkubasi selama 10-15 menit. Preparat yang sudah terwarna dibilas di bawah air kran mengalir lalu diamati di bawah mikroskop. Preparat sitologi didokumentasikan dengan kamera mikroskop (OptiLab Advance Plus ${ }^{\circledR}$, Olympus, Tokyo, Japan) pada perbesaran 100 kali.

\section{Pengamatan Makroskopik}

Pengamatan makroskopik dilakukan pada massa-massa yang telah dipisahkan dari tubuh mencit. Seluruh massa abnormal diambil, dihitung, diamati lokasi dan distribusinya, serta diukur panjang, lebar, dan tingginya dalam skala sentimeter $(\mathrm{cm})$. Massa dipalpasi untuk merasakan konsistensinya serta dipotong melintang untuk melihat bidang sayatannya.

\section{Pemeriksaan Histopatologi}

Pembuatan preparat histopatologi meliputi beberapa tahap: trimming, dehidrasi, clearing, parafinasi, embedding, sectioning, dan pewarnaan hematoxylin-eosin (HE). Trimming dilakukan setelah spesimen terfiksasi selama 24 jam di dalam neutral buffered formalin $10 \%$. Pemotongan dilakukan menggunakan blade tajam pada bagian yang mengalami lesi dengan dimensi $1 \times 1 \times 0.5 \mathrm{~cm}$ menyesuaikan dengan ketebalan kaset dan ukuran jaringan. Area yang terdapat lesi diposisikan menghadap ke bawah pada kaset.

Dehidrasi dilakukan dengan memasukkan kaset berisi spesimen ke dalam ethanol konsentrasi bertingkat berturut-turut ethanol $70 \%, 80 \%, 85 \%, 90 \%$, 95\%, ethanol absolut 1, 2 , dan 3 masing-masing selama satu jam. Clearing dilakukan dengan merendam kaset ke dalam xylol absolut 1, 2, dan 3 berturut-turut selama masing-masing 20 menit. Parafinasi dilakukan dengan memasukkan kaset ke dalam paraffin cair 1, 2, dan 3 (Surgipath ${ }^{\mathrm{TM}}$ Paraplast ${ }^{\mathrm{TM}}$ - Leica Microsystems) selama masing-masing satu jam pada suhu $56^{\circ} \mathrm{C}$.

Setelah tissue processing selesai, spesimen dipindahkan dari kaset ke dalam cetakan logam (mold) dan diposisikan area lesi menghadap ke bawah. Parafin cair lalu dituangkan ke dalam cetakan untuk proses embedding. Setelah paraffin mengeras, mold dimasukkan ke dalam freezer selama lima menit untuk memudahkan melepas blok paraffin dari mold. Blok paraffin kemudian diekspos dengan mikrotom hingga mencapai permukaan jaringan. Setelah itu, blok paraffin diiris dengan mikrotom pada ketebalan $5 \mu \mathrm{m}$. Potongan tipis blok paraffin kemudian dipindahkan ke dalam waterbath lalu ditempelkan pada kaca obyek yang telah diolesi dengan ewit (albumin).

Proses pewarnaan hematoxylin-eosin (HE) dilakukan dengan memasukan preparat ke dalam reagen-reagen dengan urutan sebagai berikut: xylol 1, 2, 3 selama masing-masing 10 menit (deparafinasi), ethanol absolut 1, 2, 3, alkohol 95\%, 90\%, 85\%, 80\%, 70\% selama masing-masing 5 menit (rehidrasi), hematoxylin selama 10 menit, alkohol asam selama 4 detik, air mengalir selama 20 menit, eosin selama 5 menit, alkohol 70\%, 80\%, 85\%, 90\%, 95\%, ethanol absolut 1, 2, dan 3 masing-masing selama 5 detik (dehidrasi), dan xylol 1, 2, 3 selama masing-masing 10 menit (clearing). Mounting dilakukan dengan menempelkan coverslip ke atas preparat yang sudah diwarnai menggunakan Entellan. Preparat histopatologi didokumentasikan dengan kamera mikroskop (OptiLab Advance Plus ${ }^{\circledR}$, Olympus, Tokyo, Japan) pada perbesaran 100 kali. Evaluasi kualitatif terhadap morfologi sel meliputi parameter berikut: bentuk dan jenis sel, derajat anisositosis, anisokaryosis, multinuklei, dan figur mitotik.

\section{HASIL DAN PEMBAHASAN}

\section{Keragaman Massa Abnormal Superfisial}

Berdasar hasil pemeriksaan histopatologi, 54 individu dengan massa abnormal superfisial pada mencit di Malang Raya terbagai menjadi dua golongan besar: massa neoplastik dan nonneoplastik. Sebanyak 36 individu memiliki massa neoplastik sedangkan 18 lainnya menunjukkan massa nonneoplastik. Seluruh massa neoplastik teridentifikasi berasal dari jaringan kelenjar yang mengarah ke adenoma atau adenosarkoma. Massa nonneoplastik menunjukkan arsitektur yang lebih beragam mulai dari krusta, abses, granulasi hingga hematoma. Proporsi temuan massa abnormal superfisial pada mencit di Malang Raya disajikan pada Gambar 1A.

Jumlah dan lokasi munculnya massa abnormal superfisial juga menunjukkan variasi yang tinggi. Sebanyak 76 massa abnormal superfisial ditemukan dari 54 individu mencit. 
Sebanyak 12 individu mencit memiliki massa abnormal superfisial ganda. Satu individu ditemukan memiliki enam massa abnormal. Titik pertumbuhan massa abnormal juga bervariasi dengan pertumbuhan massa abnormal paling sering ditemukan pada extermitas caudal dexter sebanyak 15 individu. Gambar 1B menunjukkan persentasi sebagian lokasi pertumbuhan massa abnormal yang terdokumentasi dari individu mencit yang dikoleksi.

Munculnya massa multipel pada satu individu berkaitan erat dengan tingkat metastasis massa neoplastik (Newkirk et al., 2017). Hal ini juga mengindikasikan malignansi suatu massa neoplastik. Semakin jauh penyebaran massa dari titik pertama pekembangannya, semakin malignan sifat suatu massa neoplastik (Russo dan Russo, 2000; Newkirk et al., 2017). Seluruh massa abnormal yang diidentifikasi sebagai massa neoplastik pada studi ini tumbuh dari bagian ventral tubuh mencit yang menguatkan diagnosis ke arah tumor glandula mammae. Beberapa faktor risiko yang memicu kejadian tumor glandula mammae antara lain faktor keturunan, induksi karsinogen dari pakan, paparan ultraviolet, mutasi genetik, kesalahan dalam replikasi asam nukleat akibat usia (Russo dan Russo, 2000; Lee dan Kweon, 2002). Hal ini perlu dikaji lebih lanjut untuk menekan tingkat kejadian neoplasia pada mencit khususnya yang memengaruhi efektivitas budidaya di peternak. Jenis-jenis massa neoplastik yang pernah dilaporkan pada mencit meliputi neoplasia pada jaringan hematopoiesis, pulmo, hepar, uterus, ovarium, intestinum, jaringan ikat, integumen, jaringan adiposa hingga glandula mammae (Boivin et al., 2004; Mecklenburg et al., 2013). Massa neoplastik spontan muncul pada kasus- kasus mutasi genetik, penuaan hingga idiopatik. Beberapa jenis malignansi pada glandula mammae mencit menurut Taneja et al. (2009) juga dapat disebabkan oleh mouse mammary tumor virus (MMTV). Berdasar anamnesis atau riwayat kesehatan yang tercatat, seluruh massa neoplastik tumbuh secara spontan tanpa induksi buatan.

Massa nonneoplastik yang muncul pada tubuh mencit dapat disebabkan oleh berbagai hal seperti infeksi atau respons adaptasi sel lokal seperti hiperplasia noduler atau kista (Szymanska et al., 2014). Infeksi dapat timbul akibat luka yang terkontaminasi bakteri atau kondisi mencit yang imunosupresif akibat stres jangka panjang sehingga memungkinan patogen oportunis berkembang (Newkirk et al., 2017). Luka terbuka pada area kulit dapat memicu pembentukan krusta yang keras pada permukaan kulit sedangkan granulasi juga ditemukan sebagai tahap akhir kesembuhan luka. Beberapa genus bakteri yang pernah dilaporkan berkontribusi menimbulkan abses pada mencit dan tikus antara lain genus Staphylococcus, Entamoeba, Yersinia, Bacteroides, Streptococcus, Clostridium, Fusobacterium, Escherichia, Pseudomonas, Klebsiella, dan Proteus (Kim et al., 2010; Stanley et al., 1995; Oellerich et al., 2007; Kastelein et al., 1981; Takahashi et al., 2011; Brook et al., 1984). Infeksi yang mengakibatkan radang supuratif kronis dapat membentuk abses subkutan (Newkirk et al., 2017) dan infeksi sistemik dapat menimbulkan massa-massa abses di beberapa titik di dalam tubuh (Kobayashi et al., 2015). Lesi-lesi granuloma akibat radang kronis juga mungkin ditemukan pada mencit (Mähler dan Jelinek, 2000). Berdasar pengamatan kami, beberapa hal yang berpotensi memicu terjadinya infeksi antara lain

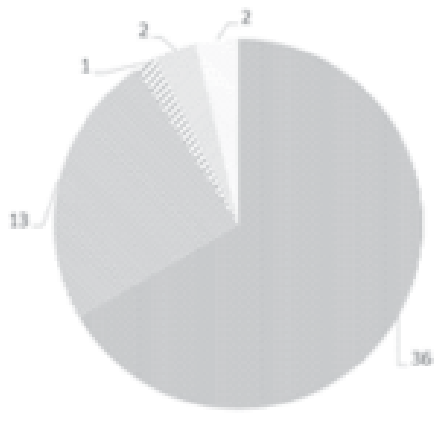

$1 \mathrm{~A}$

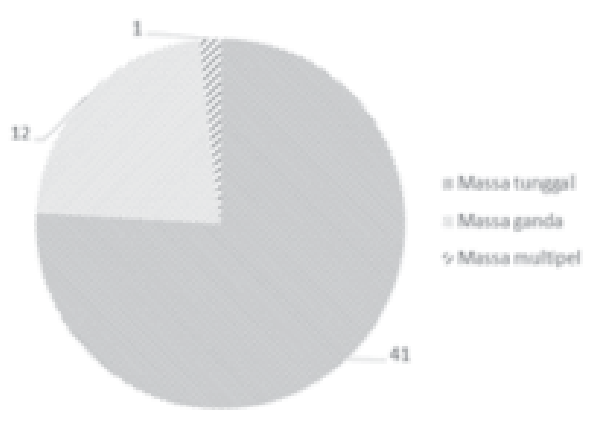

$1 \mathrm{~B}$

Gambar 1. Proporsi jumlah individu dengan temuan massa abnormal superfisial pada mencit di Malang Raya berdasar jenis massa (1A) dan jumlah massa (1B) 

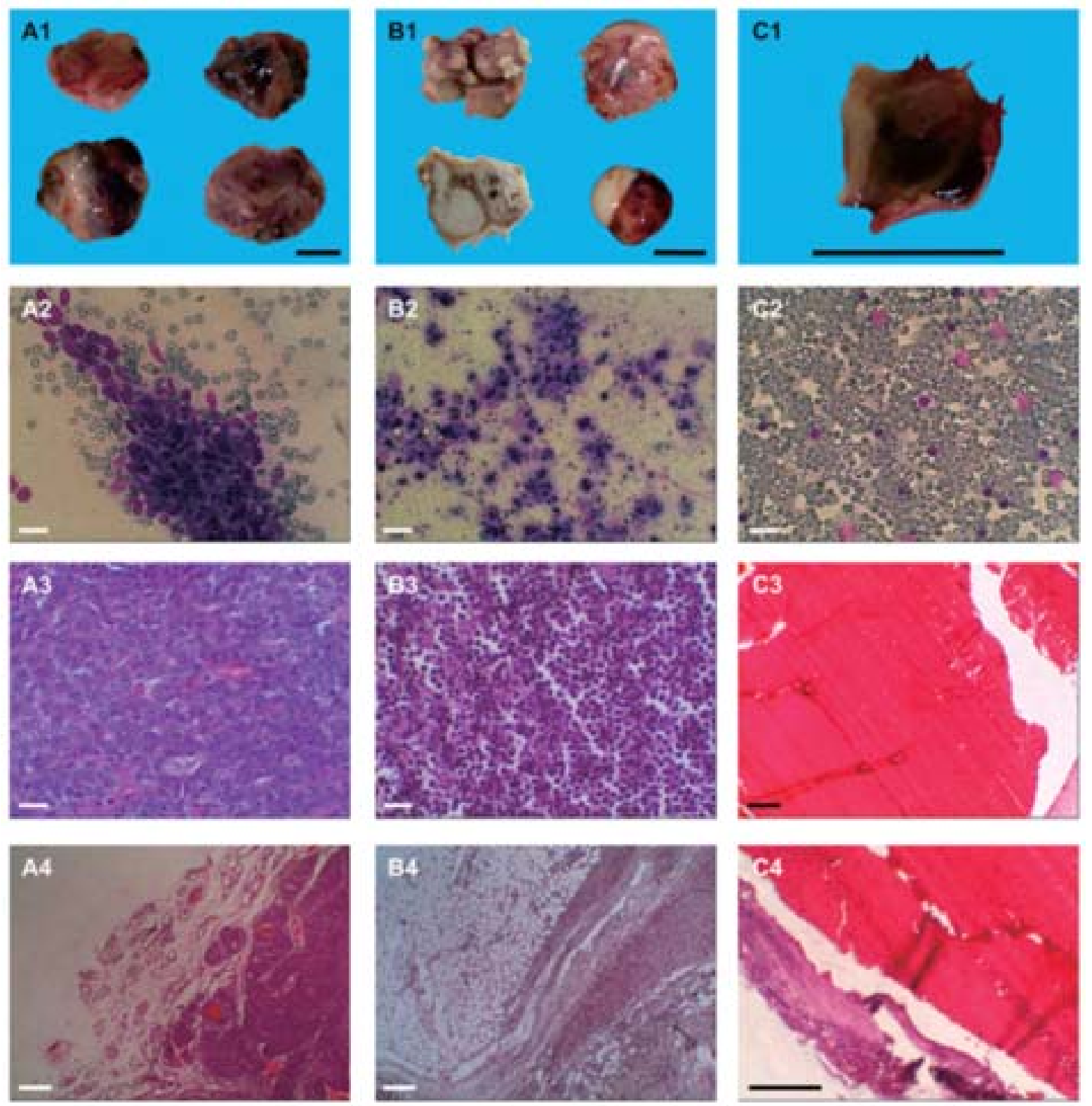

Gambar 2. Gambaran makroskopik dan mikroskopik massa abnormal superfisial pada mencit di Malang Raya. (A1) Makroskopik massa neoplastik adenokarsinoma, (A2) Preparat sitologi massa neoplastik adenokarsinoma, (A3) Histopatologi massa neoplastik adenokarsinoma (core), (A4) Histopatologi massa neoplastik adenokarsinoma (stroma). (B1) Makroskopik massa nonneoplastik abses, (B2) Preparat sitologi massa nonneoplastik abses, (B3) Histopatologi massa nonneoplastik abses (core), (B4) Histopatologi massa non-neoplastik abses (stroma). (C1) Makroskopik hematoma, (C2) Preparat sitologi hematoma, (C3) Histopatologi hematoma (core), (C4) Histopatologi hematoma (stroma). Panjang batang skala gambar makroskopik (A1, B1, C1) adalah $1 \mathrm{~cm}$. Panjang batang skala gambar A2, B2, C2 A3, dan B3 adalah $20 \mu \mathrm{m}$. Panjang batang skala gambar C3, A4, B4, dan C4 adalah $200 \mu \mathrm{m}$.

kepadatan kandang yang terlalu tinggi, pertengkaran antar mencit, luka akibat komponen kandang, dan masalah sanitasi. Hal ini masih perlu dikaji sehingga perlu dilakukan penelitian lebih lanjut terkait kejadian infeksi dengan faktor-faktor risiko terkait.

\section{Gambaran Sitologi Massa}

Aspirat massa tumor yang diulas pada gelas objek menunjukkan beberapa jenis sel yang dapat dikenali secara morfologis. Massa neoplastik memperlihatkan aspirat yang sangat seluler, mengandung sel-sel epitelial dengan 
variasi ukuran yang tinggi, beberapa spesimen memperlihatkan gambaran anisositosis dan anisokaryosis secara individual maupun terkumpul dalam klaster. Massa nonneoplastik berupa abses menunjukkan gambaran sitologi yang didominasi oleh sel-sel polimorfonuklear dan debris-debris sel nekrotik sedangkan gambaran sitologi hematoma cenderung didominasi oleh eritrosit. Sel-sel epitelial poligonal kadang ditemukan pada sitologi massa non-neoplastik yang kemungkinan bagian dari sel penyusun epidermis yang ikut terambil selama FNA. Terdapat beberapa kesamaan gambaran sitologi dari kedua jenis yang dapat mengaburkan diagnosis, antara lain muncul selsel epitelial dan eritrosit. Untuk itu, perlu dilakukan perbandingan sensitivitas dan spesifitas FNA dalam menentukan diagnosis definitif massa abnormal superfisial pada mencit.

\section{Morfologi dan Histopatologi Massa Neoplastik}

Massa neoplastik yang ditemukan berukuran antara $0,4 \times 0,25 \times 0,4 \mathrm{~cm}$ hingga $2,5 \times 1,5 \times 1,5 \mathrm{~cm}$. Demarkasi massa dengan jaringan sekitarnya jelas, terdistribusi dari fokal hingga multifokal terkoalisi, dan konsistensinya padat. Permukaan massa berwarna putih hingga kemerahan dan irisan melintang menunjukkan diskolorasi kemerahan akibat hemorrhagi. Hemorrhagi dalam hal ini berkaitan dengan pecahnya vasa darah akibat lemahnya struktur vaskularisasi di dalam massa neoplastik (Newkirk et al., 2017) atau akibat trauma saat dilakukan FNA. Massa neoplastik terletak di bagian ingunal, ekstermitas kaudal, axial, dan ekstermitas kranial. Gambar 2 (A1, B1, C1) menunjukkan gambaran makroskopis dari beberapa massa neoplastik yang ditemukan.

Secara histopatologis, massa neoplastik menunjukkan gambaran kelenjar dan sel-sel epitelial pada bagian pusat massa (core) dan jaringan pendukung berupa sel-sel fibroblast diselingi vasa darah (fibrovaskuler) pada bagian luar (stroma). Kebanyakan massa menunjukkan struktur kelenjar yang tidak utuh akibat hiperplasia dari sel epitel kelenjar. Sel-sel pleomorfik disertai dengan anisokaryosis dan anisositosis juga teramati relatif tinggi pada selsel epitel kelenjar. Beberapa area menunjukkan adanya hemorrhagi ekstensif dan nekrosis. Berdasarkan lokasi massa dan gambaran histopatologi, bahwa massa tersebut adalah jenis adenokarsinoma mammae. Beberapa studi menjelaskan bahwa terdapat beberapa jenis tumor glandula mammae pada mencit dan tikus sehingga perlu dilakukan identifikasi lebih lanjut terkait jenis tumor berdasar klasifikasi yang ada (Sass dan Dunn, 1979). Variasi arsitektur histopatologi juga pernah dilaporkan pada tumor glandula mammae pada tikus (Komitowski et al., 1982; Russo dan Russo, 2000).

\section{Abses Subkutan dan Hematoma}

Morfologi makroskopik massa nonneoplastik yang ditemukan mengarah pada abses subkutan dan hematoma. Massa nonneoplastik terukur dari 0,7 x 0,9 x $1 \mathrm{~cm}$ hingga 3,5 x 1,4 x $1 \mathrm{~cm}$. Kebanyakan massa nonneoplastik muncul pada daerah punggung dan ekor mencit dengan distribusi fokal hingga multifokal terkoalisi. Massa berupa abses cenderung memiliki konsistensi yang lunak dan berwarna putih keabuan sedangkan hematoma cenderung menunjukkan konsistensi yang lebih keras dan berwarna kemerahan. Bidang sayatan hematoma terlihat kering dan berwarna kemerahan sedangkan bidang sayatan massa abses menunjukkan struktur kantong yang berisi material pasta putih hingga mengeju. Kebanyakan massa abses yang ditemukan memiliki dinding tebal berlapis (laminar) atau terkapsulasi.

Gambaran histopatologi hematoma memperlihatkan material hipereosinofilik homogen pada pusat massa yang kemungkinan adalah bekuan eritrosit. Bagian tepi massa hematoma menunjukkan area yang lebih seluler dibandingkan bagian pusat massa. Demarkasi massa dengan jaringan terluar terlihat jelas.

Bagian pusat massa abses didominasi selsel polimorfonuklear, baik yang masih utuh maupun sudah mengalami nekrosis, dan reruntuhan jaringan. Tepi massa terlihat adanya infiltrasi sel-sel fibroblast di antara kumpulan sel-sel mononuklear. Tidak terlihat adanya sel-sel raksasa. Gambaran dinding terluar abses dan demarkasi dengan jaringan terluar tidak jelas dan beberapa menunjukkan infiltrasi sel-sel polimorfonuklear di interstsium jaringan adiposa (panikulitis).

\section{SIMPULAN}

Massa abnormal superfisial yang muncul pada mencit-mencit yang dibudidayakan di 
Malang Raya dapat berupa adenokarsinoma, abses subkutan, dan hematoma. Kejadian adenokarsinoma mendominasi jenis massa yang ditemukan disusul oleh abses subkutan dan hematoma.

\section{SARAN}

Perlu kajian lebih lanjut untuk mengetahui jenis adenokarsinoma berdasar jaringan pembentuk dan arsitekturnya. Pewarnaan imunohistokimia (IHK) dapat digunakan untuk mendeteksi dan membedakan setiap tipe adenokarsinoma. Munculnya massa abnormal pada mencit memberikan dampak pada produktivitas dan kualitas mencit budidaya sehingga kajian terkait faktor risiko dapat membantu peternak dalam mencegah maupun mengantisipasi munculnya massa abnormal dan kerugian ekonomi.

\section{UCAPAN TERIMA KASIH}

Penelitian ini didanai oleh hibah penelitian DPP SPP Fakultas Kedokteran Hewan Universitas Brawijaya pendanaan tahun 2020 nomor kontrak I 301 /LN I 0.Fl 3.06 iPN/2020.

\section{DAFTAR PUSTAKA}

Boivin GP, Washington K, Yang K, Ward JM, Pretlow TP, Russell R, Besselsen DG, Godfrey VL, Doetschman T, Dove WF. 2003. Pathology of mouse models of intestinal cancer: consensus report and recommendations. Gastroenterology 124(3): 762-777.

Brook I, Hunter V, Walker RI. 1984. Synergistic effect of Bacteroides, Clostridium, Fusobacterium, anaerobic cocci, and aerobic bacteria on mortality and induction of subcutaneous abscesses in mice. J Infect Dis 149(6): 924-928.

Ghartimagar D, Ghosh A, Ranabhat S, Shrestha M, Narasimhan R, Talwar O. 2011. Utility of fine needle aspiration cytology in metastatic lymph nodes. J Pathol Nepal 1(2): 92-95.

Kastelein P, Van Steenbergen TJM, Bras JM, De Graaff J. 1981. An experimentally induced phlegmonous abscess by a strain of
Bacteroides gingivalis in guinea pigs and mice. Antonie Van Leeuwenhoek 47(1): 1-9.

Kengkoom K, Ampawong S. 2017. Staphylococcus sciuri associated to subcutaneous abscess and dermatitis in ICR mouse. Arq Bras Med Vet Zootec 69(1): 117-122.

Kiehl AR, Mays MBC. 2016. Atlas for the Diagnosis of Tumors in the Dog and Cat. Ames, Iowa. John Wiley \& Sons. Hlm. 213224.

Kim HK, DeDent A, Cheng AG, McAdow M, Bagnoli F, Missiakas DM, Schneewind O. 2010. IsdA and IsdB antibodies protect mice against Staphylococcus aureus abscess formation and lethal challenge. Vaccine 28(38): 6382-6392.

Kobayashi SD, Malachowa N, DeLeo FR. 2015. Pathogenesis of Staphylococcus aureus abscesses. Am J Pathol 185(6): 1518-1527.

Komitowski D, Sass B, Laub W. 1982. Rat mammary tumor classification: notes on comparative aspects. J Natl Cancer Inst 68(1): 147-156.

Lee CH, Kweon OK. 2002. Mutations of p53 tumor suppressor gene in spontaneous canine mammary tumors. J Vet Sci 3(4): 321-326.

Mähler M, Jelinek F. 2000. Granulomatous inflammation in the tails of mice associated with Mycobacterium chelonae infection. Lab Anim 34(2): 212-216.

Mecklenburg L, Kusewitt D, Kolly C, Treumann S, Adams ET, Diegel K, Yamate J, Kaufmann W, Müller S, Danilenko D. 2013. Proliferative and non-proliferative lesions of the rat and mouse integument. $J$ Toxicol Pathol 26(3_Suppl): 27S-57S.

Newkirk MK, Brannick EM, Kusewitt DF. 2017. Neoplasia and Tumor Biology In: Zachary SF (Ed). Pathologic Basis of Veterinary Disease. Sixth Edition. Elsevier Health Sciences, St. Louis-Missouri, pp. 305-308.

Oellerich MF, Jacobi CA, Freund S, Niedung K, Bach A, Heesemann J, Trülzsch K. 2007. Yersinia enterocolitica infection of mice reveals clonal invasion and abscess formation. Infect Immun 75(8): 3802-3811.

Parkinson CM, O'Brien A, Albers TM, Simon MA, Clifford CB, Pritchett-Corning KR. 2011. Diagnostic necropsy and selected 
tissue and sample collection in rats and mice. J Vis Exp (54): e2966.

Prejean JD, Peckham JC, Casey AE, Griswold DP, Weisburger EK, Weisburger JH. 1973. Spontaneous tumors in Sprague-Dawley rats and Swiss mice. Cancer Res 33(11): 27682773.

Russo J, Russo IH. 2000. Atlas and histologic classification of tumors of the rat mammary gland. J Mammary Gland Biol Neoplasia 5(2): 187-200.

Sass B, Dunn TB. 1979. Classification of mouse mammary tumors in Dunn's miscellaneous group including recently reported types. $J$ Natl Cancer Inst 62(5): 1287-1293.

Stanley SL, Zhang T, Rubin D, Li E. 1995. Role of the Entamoeba histolytica cysteine proteinase in amebic liver abscess formation in severe combined immunodeficient mice. Infect Immun 63(4): 1587-1590.

Szymanska H, Lechowska-Piskorowska J, Krysiak E, Strzalkowska A, UnrugBielawska K, Grygalewicz B, Skurzak H, Pienkowska-Grela B, Gajewska M. 2014.
Neoplastic and nonneoplastic lesions in aging mice of unique and common inbred strains contribution to modeling of human neoplastic diseases. Vet Pathol 51(3): 663679.

Takahashi Y, Yoshida A, Nagata E, Hoshino T, Oho T, Awano S, Takehara T, Ansai T. 2011. Streptococcus anginosus 1 cysteine desulfhydrase gene expression is associated with abscess formation in BALB/c mice. $\mathrm{Mol}$ Oral Microbiol 26(3): 221-227.

Taneja P, Frazier DP, Kendig RD, Maglic D, Sugiyama T, Kai F, Taneja NK, Inoue K. 2009. MMTV mouse models and the diagnostic values of MMTV-like sequences in human breast cancer. Expert Rev Mol Diagn 9(5): 423-440.

Underwood W, Anthony R. 2020. AVMA Guidelines for the Euthanasia of Animals: 2020 Edition. Retrieved on March, 30(2020): 2020-01.

Weber K. 2017. Differences in types and incidence of neoplasms in Wistar Han and SpragueDawley rats. Toxicol Pathol 45(1): 64-75. 